\title{
Clinical Parasitology and Parasitome Maps as Old and New Tools to Improve Clinical Microbiomics
}

\author{
Stefania Pane ${ }^{1,+}\left(\mathbb{D}\right.$, Maria Vittoria Ristori ${ }^{1,2,+}$, Simone Gardini $^{3}$, Alessandra Russo ${ }^{1}$, Federica Del Chierico ${ }^{2}(\mathbb{D}$ \\ and Lorenza Putignani 1,2,*(D) \\ 1 Microbiology and Diagnostic Immunology Unit, Unit of Microbiomics, Bambino Gesù Children's Hospital, \\ IRCCS, 00146 Rome, Italy; stefania.pane@opbg.net (S.P.); mvittoria.ristori@opbg.net (M.V.R.); \\ alessandra.russo@opbg.net (A.R.) \\ 2 Multimodal Laboratory Medicine Research Area, Unit of Human Microbiome, Bambino Gesù Children's \\ Hospital, IRCCS, 00146 Rome, Italy; federica.delchierico@opbg.net \\ 3 GenomeUp, Via Nemorense 91, 00199 Rome, Italy; simone@genomeup.com \\ * Correspondence: lorenza.putignani@opbg.net; Tel.: +39-0668592598 (ext. 4076) \\ + These authors contributed equally to this work.
}

check for updates

Citation: Pane, S.; Ristori, M.V.; Gardini, S.; Russo, A.; Del Chierico, F.; Putignani, L. Clinical Parasitology and Parasitome Maps as Old and New Tools to Improve Clinical Microbiomics. Pathogens 2021, 10, 1550. https://doi.org/10.3390/ pathogens 10121550

Academic Editors: Donato Traversa, Angela Di Cesare and Simone Morelli

Received: 23 September 2021

Accepted: 25 November 2021

Published: 28 November 2021

Publisher's Note: MDPI stays neutral with regard to jurisdictional claims in published maps and institutional affiliations.

Copyright: (c) 2021 by the authors. Licensee MDPI, Basel, Switzerland. This article is an open access article distributed under the terms and conditions of the Creative Commons Attribution (CC BY) license (https:// creativecommons.org/licenses/by/ $4.0 /)$.

\begin{abstract}
A growing body of evidence shows that dysbiotic gut microbiota may correlate with a wide range of disorders; hence, the clinical use of microbiota maps and fecal microbiota transplantation (FMT) can be exploited in the clinic of some infectious diseases. Through direct or indirect ecological and functional competition, FMT may stimulate decolonization of pathogens or opportunistic pathogens, modulating immune response and colonic inflammation, and restoring intestinal homeostasis, which reduces host damage. Herein, we discuss how diagnostic parasitology may contribute to designing clinical metagenomic pipelines and FMT programs, especially in pediatric subjects. The consequences of more specialized diagnostics in the context of gut microbiota communities may improve the clinical parasitology and extend its applications to the prevention and treatment of several communicable and even noncommunicable disorders.
\end{abstract}

Keywords: parasites; microbiota; Faecal Microbiota Transplantation (FMT)

\section{Introduction}

The intestinal environment is an ecosystem where biological and chemical interactions occur at various organizational levels between host, parasites, and microbial communities, greatly affecting human health and physiology.

Considering the gut microbiota at the taxonomic level, we can observe a significant variation among individuals, each harboring a unique collection of bacterial species, which may change over time and could be considered a fingerprint [1-3].

The microbiota at the gut microenvironment level provides important protective, immune regulatory and metabolic functions. The defensive mechanism against pathogenic bacteria is exerted by the barrier effect of the intestinal epithelium, playing a major role in protecting the host and representing an important obstacle to pathogenic invasion $[4,5]$. Indeed, gut microbiota has an important role in immunological activation and development, as demonstrated in many metabolic and autoimmune diseases [6], by influencing host immune response [7-11]. The balance of the gut microbial ecosystem, eubiosis, is an important concept. Indeed, the eubiotic gut microbiota is characterized by a preponderance of potentially beneficial species, belonging mainly to the two bacterial phylum Firmicutes and Bacteroidetes, and, potentially, pathogenic species such as Proteobacteria. In the dysbiosis state, "bad bacteria" predominate "good bacteria" [12-14].

Moreover, environmental factors, such as age, diet, stress, drugs, and infections including parasitosis, strongly influence the composition of the human microbiota [15-18]. Nowadays, it is evident that the intestinal microbiota has an important impact on human 
pathophysiology, also regulating pathogenic burden [19]. Intestinal helminths may directly influence the immune system through their effects on both gut luminal and mucosal microbiota [20]. Indeed, Th2 cells have an important role in combatting parasitic infections [21]. However, in existing literature, there is conflicting evidence on the effect of parasites on microbiota ecology and function and their impact on health and disease balance.

Within this complex scenario, intestinal citizens (e.g., viruses, mycetes, and parasites) interact with the microbial community, modifying the balance between host and gut microbiota $[4,22]$. The intestinal microenvironment, considered as a whole community, provides an important protective mucosal defense mechanism, but there is evidence that change in the composition of the commensal microbiota alters the gut environment, making this composition vulnerable to pathogenic organisms [23-25]. Many factors such as antibiotics, psychological stress, physical stress, modern diet, and hygiene can affect microbial stability, and thus contribute to intestinal dysbiosis [13].

\section{Role and Relationship amongst Gut Microbiota Citizens}

In addition to bacteria, other key microorganisms, such as yeasts and filamentous fungi, viruses, and phages, are present in the gut [26,27]. Moreover, for $\sim 25 \%$ of the world's population, the gut microbiota also comprises intestinal protozoan and worms, namely meiofauna [28,29].

The diversity of meiofauna living on or in our bodies is associated to all metazoans with dimensions between $30 \mu \mathrm{m}$ and $1 \mathrm{~mm}$. Many members of the meiofauna significantly affect morbidity and mortality, including fungi (e.g., Candida, Aspergillus), unicellular protozoa (e.g., Giardia, Entamoeba), and helminthic worms (e.g., Ascaris) (Figure 1) [30].

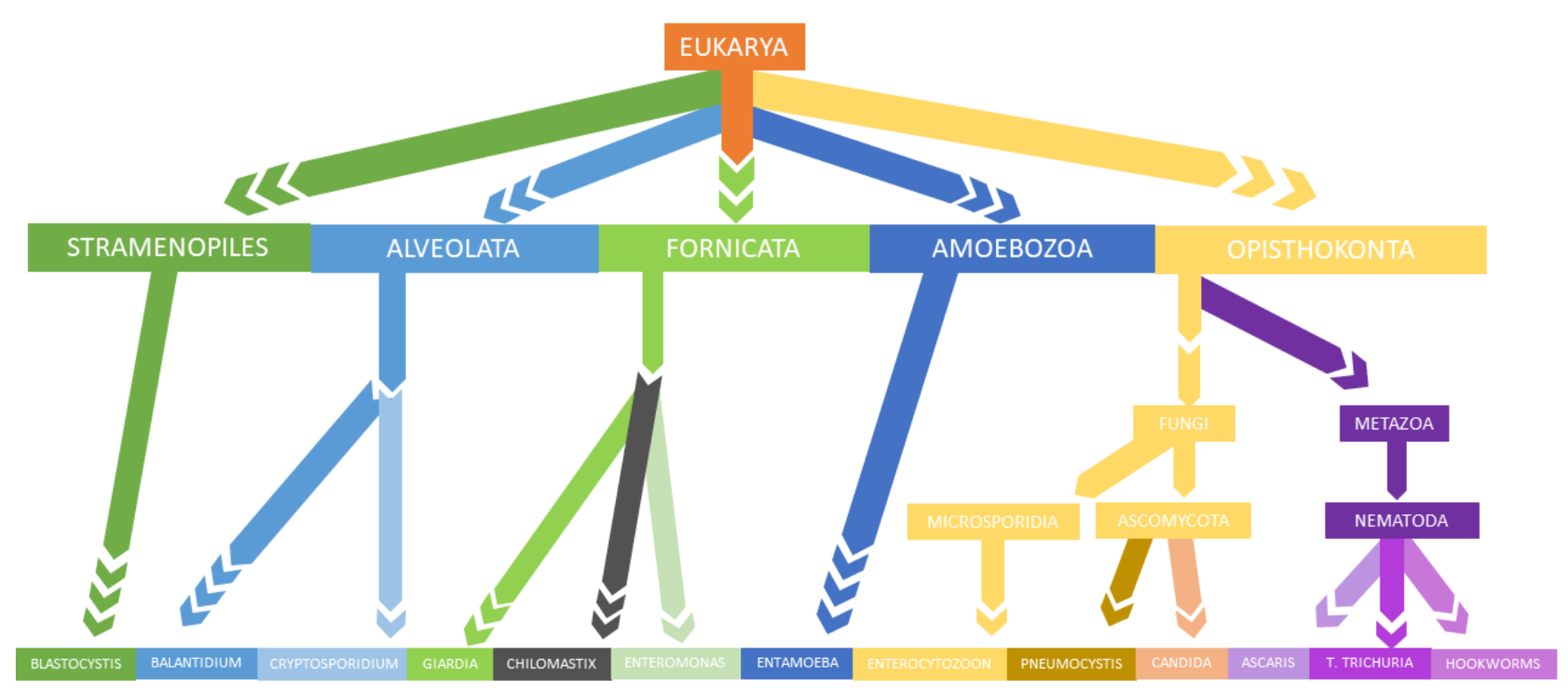

Figure 1. Simplified taxonomic overview of the meiofauna of the human GI tract.

Sequencing technologies allow us to analyze the global diversity of the meiofauna of the human gastrointestinal tract to intimately demonstrate gastrointestinal meiofauna may be important in promoting health or disease. Several studies indicate that diet can influence the proportions of the meiofauna and that there is the possibility of trans-kingdom interactions in the gastrointestinal tract [30] (Figure 1).

All these microorganisms offer additional dimensions to the investigation of the host microorganism and microorganism-microorganism interactions. These interplays can be exploited only by combined models obtained by metagenomics, metabolomics and metaproteomics harmonization and integration [31], aiming at producing decision support systems for disease stratification in medicine [32]. 
All microbial inhabitants may have both beneficial and detrimental roles in the human health, including improvement of microbial resilience, immune evasion, maintenance of physiologic processes, but even alteration of microbial communities [33]. Bacteriophages in the gut are largely unexplored, despite their potential to regulate bacterial communities and thus human health $[34,35]$. Indeed, experimental limitations still successfully affect the isolation of phages and genome annotation as well as the full characterization of virus-human populations [36]. Some studies have highlighted the uniqueness of phage communities in individuals and their capacity to be stable in a healthy gut [37]. Remarkably, the stability of the viral genome is probably responsible for the stableness of bacteria and microbiota metagenomes [38]. However, there are still only a few studies on the role of the virome in the host's intestinal microbiota ecosystem [39].

Fungi are normal inhabitants of the mammalian gastrointestinal tract. In fact, the human gut is colonized by more than 50 genera of fungi [40]. In particular, the gut is characterized by the presence of Candida, Saccharomyces and Cladosporium species. Nutritional modification may have an effect on the fungal microbiota; in particular, plant-based diets increase the levels of Candida, whereas animal-based diets improve the presence of Penicillium species [41,42]. Indeed, fungi compose a very small portion of gut microbiota but play determinative roles in the homeostasis of the gut bacterial composition and the mucosal immune responses. An interkingdom correlation between bacteria and fungi has been suggested. Alterations in the composition and function of the gut microbiota are a usual event in patients who suffer from IBD. Although the main reason for this alteration is not clear, the interaction between gut bacteria and gut fungi seems to be an important subject in IBD patients [43].

So, intestinal parasites, both protozoans and metazoan (nematodes and platyhelminths), interact with the microbial community, modifying the balance between host and gut microbiota [44].

\section{Parasites and Gut Microbiota Profiling}

Parasitic infections represent a significant health problem, particularly in underdeveloped and developing countries. Soil-transmitted helminths (STHs), e.g., Strongyloides stercoralis and Trichuris trichiura, are common intestinal parasites, followed by blood flukes (i.e., Schistosoma spp.) and filarial worms (e.g., Wuchereria and Brugia). Generally speaking, intestinal parasitic infections may have a low impact in immunocompetent subjects; however, they can potentially become a major issue in vulnerable groups. In fact, helminth infections produce malnutrition, physical damage, and cognitive development complications in children [45]. Furthermore, a wide range of protozoans are common parasites of the human gastro-intestinal tract (e.g., Cryptosporidium spp., Entamoeba histolytica, Giardia duodenalis). The spectrum of clinical manifestations of protozoan infections varies from chronic diarrhea or weight loss, or mild self-limiting illness to acute disease, until malabsorption $[29,46,47]$, as well as the modality of transmission, zoonotic or anthroponotic, particularly investigated as reported for Apicomplexan parasites [48]. A study conducted on packaged salads highlighted the presence of protozoan contamination, such as Giardia duodenalis, Cryptosporidium spp., Toxoplasma gondii, and Cyclospora cayetanensis, through microscopy and molecular analyses, concluding that $4.2 \%$ of the samples were contaminated by at least one protozoan species, and $0.6 \%$ of samples with at least two protozoa [49].

Together with trillions of microorganisms, i.e., archaea, viruses, bacteria, and eukaryotes residing in the GI tract, parasitic worms establish the "macrobiota" [50]. The microbiota of a host may strongly interfere with the survival and physiology of many parasites and, consequently, with the outcome of many parasitic infections. During parasite infections, the interaction between the gut microbiota and the helminths has been associated with the establishment of the infection, the clinical manifestations, and even immune modulation [51,52]. However, both increased and decreased gut microbiota diversity has been observed in subjects affected by intestinal parasites [53-57]. 
Experiments performed in murine models of intestinal schistosomiasis have suggested interactions between Schistosoma parasites and the host gut microbiota with a direct impact on the intestinal microbial communities [58]. In a study by Alba Cortés et al., the gut microbiome composition of the host actually influenced the host's susceptibility to $S$. mansoni infection, as well as infection-associated changes in gut microbiota profiles [58]. Some studies have evidenced that Necator americanus infection could alleviate chronic inflammation in celiac disease and improve prokaryotic species richness, reestablishing the eubiosis and immune homeostasis [59]. In a case report on Strongiloides stercoralis infection, gut microbiota composition was associated with enrichment in Bifidobacterium, Blautia, Ruminococcus, Bacteroides, Corynebacterium, Colinsella, Streptococcus, Coprococcus, and Oscillospora genera, and a decrease in Staphylococcus, Lactobacillus, and Pediococcus. The authors suggested a putative direct or immune-mediated ability of $S$. stercoralis to promote the increase in bacterial diversity [60]. In some studies conducted in a rural African population, the authors showed a characteristic gut microbiota ecology in patients carrying Entamoeba colonization [61-63] (Table 1).

A review of the literature tried to study in depth the mutual influences of intestinal nematodes and host-gut microbiota, highlighting the potential beneficial effects (i.e., promotion of eubiosis) through the production of useful metabolites (i.e., short-chain fatty acids, SCFA) [60]. Conversely, nematode infection may promote dysbiosis due to promotion of pathogenic bacterial species and decrease in mutualistic commensal. Authors exemplified the nematode-microbiota interactions and their impact on the host immune response [64].

A shotgun metagenomics study on samples of patients with the Blastocystis spp. infection showed a very strong association between the presence of Blastocystis spp. and the abundance of archaeal organisms (Methanobrevibacter smithii) [65]. Additionally, another study showed a decrease in Blastocystis in individuals with the Bacteroides enterotype compared to subjects with the Ruminococcus or Prevotella enterotypes [66]. Audebert et al. highlighted a high microbiota diversity, increased abundance of Clostridia, and low abundance of Enterobacteriaceae in Blastocystis-colonized patients, suggesting that Blastocystis infection may be associated with a healthy gut microbiota [67]. Conversely, another study did not highlight significant modifications in the gut microbiota of Blastocystis positive subjects affected by irritable bowel syndrome [68]. In a rat model of Blastocystis ST3 infection, the colonization altered gut microbiota composition, but not richness, inducing only mild gut inflammation but no clinical symptoms. In addition, the long-term Blastocystis exposure appeared to promote faster recovery from colitis, suggesting that Blastocystis may alter the gut ecosystem in a protective way and promote faster recovery [69]. Conversely, in healthy subjects, the fermentation by anaerobic bacteria and Blastocystis induced an increased SCFA production [70]. A further study has developed a bioinformatic pipeline to detect Blastocystis subtypes (STs) from shotgun metagenomics data, identifying Blastocystis as a common component of the healthy gut microbiome [65]. The authors showed how metagenomics could play an important role in advancing evidence on population genomics of human parasites. Therefore, through DNA sequencing-based methods, it might be possible to address the role of Blastocystis and Dientamoeba as commensal components of healthy gut microbiota rather than pathogenic microorganisms.

In other papers, B. hominis and D. fragilis appeared to be more or less obligated eukaryotic members of the gut microbiota [71-73] and less frequent in subjects with intestinal diseases and metabolic disorders [65,74-76].

Conversely, other studies have highlighted the possible role of $D$. fragilis and $B$. hominis as infectious agents, providing a relationship with gut microbiota profiles and host phenotypic features, including microbiota dysbiosis or eubiosis [70]. Indeed, in this article, Stensvold C.R. et al. discussed the possible role of Blastocystis as an indicator of disease-related gut microbiota profiles in subjects affected by gut dysbiosis [70] or as an indicator of eubiosis in healthy subjects.

Since the composition of the intestinal bacterial population affects the impact of the infection of protozoans, or vice versa, the modulation of different components of the 
microbiota could be used to prevent or attenuate intestinal protozoan infection and the ultimate outcome of parasitic disease (Table 1). Indeed, microbial signatures associated with parasitic infections may represent the actual link with the gut microbiota shape, playing a role in unveiling the susceptibility to infections and in their clinical outcome in terms of disease onset, progression, and severity [77].

Table 1. Gut microbiota profiles associated to parasitic infections.

\begin{tabular}{|c|c|c|c|c|c|}
\hline Reference & Parasite & Type of Infection & $\begin{array}{l}\text { Type of } \\
\text { Study }\end{array}$ & $\begin{array}{c}\text { Type of } \\
\text { Sequencing }\end{array}$ & Gut Microbiota Composition \\
\hline [67] & Blastocystis & Natural & $\begin{array}{l}\text { Human } \\
\text { study }\end{array}$ & $\begin{array}{l}16 \mathrm{~S} \text { rDNA } \\
\text { sequencing }\end{array}$ & $\begin{array}{c}\text { Increase in Clostridia, Mollicutes, } \\
\text { Clostridiales, Ruminococcaceae and } \\
\text { Prevotellaceae. } \\
\text { Decrease in Bacilli, Lactobacillales, } \\
\text { Enterococcaceae, Streptococcaceae, } \\
\text { Lactobacillaceae and Enterobacteriaceae. }\end{array}$ \\
\hline$[68]$ & Blastocystis & Natural & $\begin{array}{l}\text { Human } \\
\text { study }\end{array}$ & $\begin{array}{l}16 S \text { rDNA } \\
\text { sequencing }\end{array}$ & No significant change. \\
\hline [69] & Blastocystis & $\begin{array}{l}\text { Mouse infected } \\
\text { with Blastocystis } \\
\text { ST3 }\end{array}$ & $\begin{array}{l}\text { Murine } \\
\text { model }\end{array}$ & $\begin{array}{l}16 S \text { rDNA } \\
\text { sequencing }\end{array}$ & $\begin{array}{l}\text { Increase in Bilophila and Butyricimonas in } \\
\text { the Blastocystis-colonized group. } \\
\text { Decrease in Defluviitaleaceae. }\end{array}$ \\
\hline$[65]$ & Blastocystis & Natural & $\begin{array}{l}\text { Human } \\
\text { study }\end{array}$ & $\begin{array}{l}\text { Shotgun } \\
\text { metagenomics }\end{array}$ & $\begin{array}{l}\text { Increase in Firmicutes and Clostridiales. } \\
\text { Decrease in Bacteroides. }\end{array}$ \\
\hline [61] & Entamoeba & Natural & $\begin{array}{l}\text { Human } \\
\text { study }\end{array}$ & $\begin{array}{l}16 \mathrm{~S} \text { rDNA } \\
\text { sequencing }\end{array}$ & $\begin{array}{c}\text { Increase in Bacteroidales, Mollicutes, } \\
\text { Christensenellaceae, Elusimicrobiaceae, } \\
\text { Ruminococcaceae, Paraprevotellaceae, } \\
\text { Treponema, Parabacteroides, Streptococcus, } \\
\text { Butyrivibrio, Oscillospira, Desulfovibrio and } \\
\text { Ruminococcus bromii. } \\
\text { Decrease in Prevotella, Prevotella copri. }\end{array}$ \\
\hline [62] & Entamoeba & Natural & $\begin{array}{l}\text { Human } \\
\text { study }\end{array}$ & $\begin{array}{l}16 S \text { rDNA } \\
\text { sequencing }\end{array}$ & $\begin{array}{c}\text { Positive correlation between } \\
\text { Bifidobacterium vs. B. fragilis, and } \\
\text { Prevotella vs. Bacteroides. } \\
\text { Negative correlation between } \\
\text { Bifidobacterium vs. Bacteroides. }\end{array}$ \\
\hline [63] & Entamoeba & $\begin{array}{l}\text { Culture of } E \text {. } \\
\text { histolytica }\end{array}$ & $\begin{array}{l}\text { Culture } \\
\text { study }\end{array}$ & $\begin{array}{l}16 \mathrm{~S} \text { rDNA } \\
\text { sequencing }\end{array}$ & $\begin{array}{c}\text { Increase Lactobacillaceae, Clostridiaceae, } \\
\text { Erysipelotrichaceae, and } \\
\text { Bifidobacteriaceae. }\end{array}$ \\
\hline [58] & Schistosoma & $\begin{array}{l}\text { Infected with } S \text {. } \\
\text { mansoni cercariae } \\
\quad(\text { Sm-exp })\end{array}$ & $\begin{array}{l}\text { Murine } \\
\text { model }\end{array}$ & $\begin{array}{c}16 \mathrm{~S} \text { rDNA } \\
\text { sequencing }\end{array}$ & $\begin{array}{l}\text { The authors supposed that susceptibility } \\
\text { to Schistosoma infection in mice is } \\
\text { partially dependent on the composition } \\
\text { of the host baseline microbiota. }\end{array}$ \\
\hline [59] & $\begin{array}{l}\text { Necator } \\
\text { americanus }\end{array}$ & $\begin{array}{l}\text { Percutaneous } \\
\text { infection with } \\
\text { third-stage larvae } \\
\text { N. americanus }\end{array}$ & $\begin{array}{l}\text { Longitudinal } \\
\text { study }\end{array}$ & $\begin{array}{l}16 \mathrm{~S} \text { rDNA } \\
\text { sequencing }\end{array}$ & $\begin{array}{c}\text { Increase in Tenericutes, Mollicutes and } \\
\text { Parabacteroides. }\end{array}$ \\
\hline
\end{tabular}

Increase in Bifidobacterium, Blautia, Ruminococcus, Bacteroides,

$\begin{array}{ccc}\text { [60] } \begin{array}{c}\text { Strongiloides } \\ \text { stercoralis }\end{array} \quad \text { Natural } & \text { Case report } & \begin{array}{c}16 \mathrm{SDNA} \\ \text { sequencing }\end{array}\end{array}$
Corynebacterium, Colinsella, Streptococcus, Coprococcus, and Oscillospora.

Decrease in Staphylococcus, Lactobacillus, and Pediococcus. 


\section{New Molecular Approaches in Translational and Clinical Parasitology}

In January 2019, the Parasite Microbiome Project (PMP) began to understand the role of parasite-associated gut microbiota in the pathophysiology of helminthiases [78]. The PMP tried to draw best practices for experimental studies to ensure reliable comparisons between data sets and the introduction of appropriate controls to identify possible environmental microbial contaminants [78]. In a recent review, the authors suggested four elements that must be considered when the scientist wants to generate reliable and reproducible data [50]. As a first step, they propose generating appropriate negative controls ("blanks") in each step of the experiment, followed by the microscopy-based visualization of helminth-associated bacteria to identify and characterize worm microbiomes across different helminth tissues and developmental stages. Best practices are becoming more and more important because clinical metagenomic next-generation sequencing (mNGS) is rapidly moving from research to clinical laboratories. Chiu et al. focused on the challenges of implementing mNGS in the clinical laboratory and addressing potential solutions for maximizing its impact on patient care and public health [79]. In fact, metagenomic methods (NGS) are the new approach that microbiologists and parasitologists should undertake to improve accuracy and sensitivity, with respect to the classical approach based on the microscopical method, which may be affected by ambiguities and subjective interpretations [80]. Indeed, major usage of different genomic approaches, such as metataxonomics and metagenomes [81], may assist in reducing ambiguities and subjective interpretation in parasite description and assessing their relationship with microbial communities. Marchesi et al. suggested metataxonomics to assess fine metataxonomic tree descriptions of the entire microbiota and metagenomics to assemble microbial genomes and characterize new genes after annotation through shotgun sequencing [81]. Particularly, metataxonomics refers to targeted sequencing of $16 \mathrm{~S}$ rRNA gene hypervariable regions [82] andallows representative bacterial taxonomic description [83].

In this context, remarkable is the choice of primers able to reduce potential bias in the representation of entire taxonomic units [84-86]. The sequencing output represents a set of clusters of close related sequences, called operational taxonomic units (OTUs) [87]. Through bioinformatic OTUs analysis, it is possible to assess the level of microbial community diversity, both in terms of evenness and richness [88] and the degree of divergence between different ecosystems or sample types [89].

On the contrary, shotgun metagenomics is based on DNA molecules, which are randomly broken into fragments that are then sequenced [90]. Hence, the shotgun metagenomic approach provides major information on the taxonomic composition and inferred functional genes, thus fully characterizing the sample, despite requested high coverage [91].

Clinical applications of metagenomic sequencing include direct identification of microorganisms from primary clinical samples, antimicrobial resistance prediction by characterization of resistance genes, detection of species-level or strain-level virulence determinants, and antiviral resistance prediction. Furthermore, by means of NGS techniques, it is now possible to analyze the onset and progression of infectious diseases in acute and chronic stages [79]. The current challenge will become the agnostic approach through the complete characterization of enteric microbial communities, shallow metagenomics, and trans-kingdom metagenomics (Figures 2 and 3). 


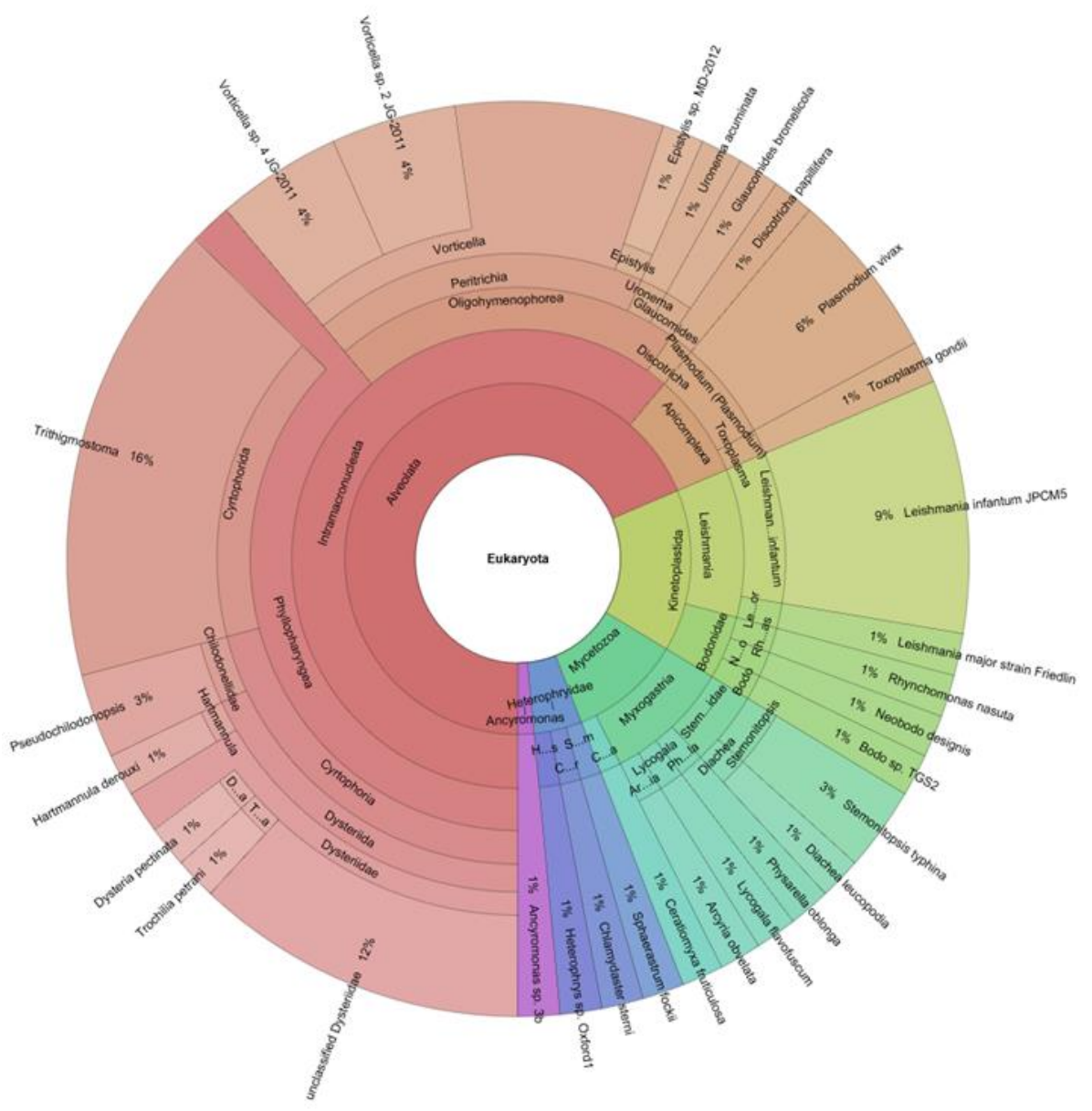

Figure 2. An example of gut parasitome kronos graph obtained by applying agnostic metagenomics pipelines and referred to Eukaryota superkingdom.

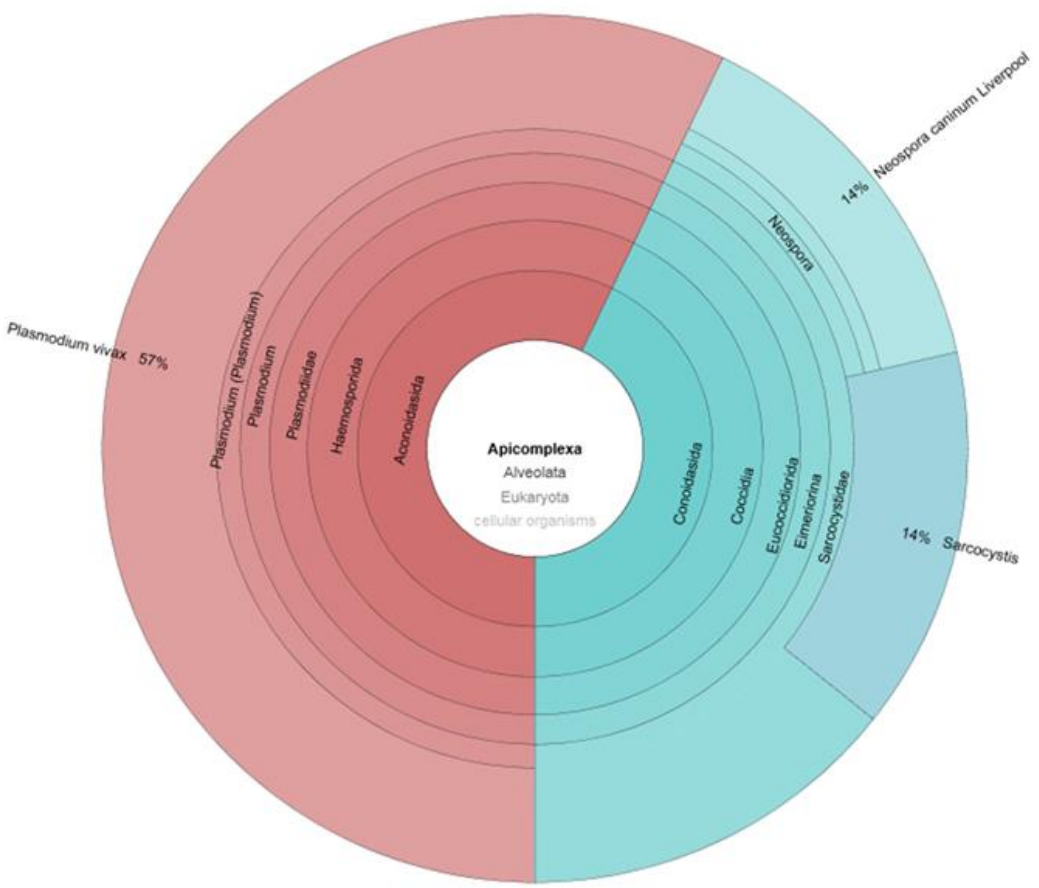

Figure 3. An example of gut parasitome kronos graph obtained by applying agnostic metagenomics pipelines and referred to Apicomplexa phylum. 


\section{Gut Microbiota Profiling as Tools to Restore and Modulate Gut Microbiota}

Gut dysbiosis may be harmful to human beings, leading to organ-localized inflammation, delocalized low inflammation, neuro-inflammation, and mucosal tissue damage predisposed to pathological conditions, such as in the case of obesity, liver steatosis, autism, and PANDAs [92-95]. Regarding inflammatory mechanisms, amongst infectious diseases, the infection by $C$. difficile, exerted by the toxin causing gastrointestinal illness, is associated with a wide spectrum of severity, ranging from mild diarrhea to pseudomembranous colitis, toxic megacolon, sepsis, and death 17 [96,97]. C. difficile, a Gram-positive spore-forming bacillus, is considered a member of the normal gut microbiota. Regardless, its abnormal growth is suppressed by other more dominant anaerobes [98]. The gut colonization of $C$. difficile is reversely related with host age, growing in early infancy and senescence, and decreasing in adulthood. Furthermore, gut colonization of $C$. difficile depends on the loss of the commensal microbiota barrier, loss potentiated by antimicrobial therapies.

In this context, $C$. difficile infection is responsible for the initiation of the cascade of inflammatory processes, which may play an important and destructive role in the initiation and perpetuation of intestinal inflammation [98]. Patients with recurrent $C$. difficile infections are characterized by almost monomicrobial bacterial distributions of the fecal microbiota [99]. A decrease in bacterial diversity and a strong variation in global distribution of OTUs are, indeed, registered in the fecal microbiota profiling of adult patients who present $C$. difficile infections [99]. In particular, a statistically significant increase in Firmicutes and a decrease in Bacteroidetes phyla, compared to healthy subjects are observed in the patients, as well as an increase in Clostridiaceae and Erysipelotrichaceae families (Figure 4). Remarkably, in microbiota profiles associated with infectious agents, the dysbiosis index (DI) is usually very high, based on the prevalence of few microbial taxa, as reported by diagnostic maps obtained for $C$. difficile infection, for which observed dysbiosis values are actually very high (DI $>35 \%$ ) (https: / / www.ospedalebambinogesu.it/ parassitologia-98785/, (accessed on 20 September 2021)) (Lorenza Putignani and Antonio Gasbarrini, oral communication, $24^{\circ}$ Congresso Nazionale delle Malattie Digestive, Rome, FISMAD 23 March 2018) (Patent IT: PCT40659, EU: PCT/IT2017/000119, Metagenomic Method for in vitro diagnosis of intestinal disbiosis).

Fecal microbiota transplantation (FMT) has achieved a major role in the clinical management of $C$. difficile infections. In these cases, the transplantation is followed by a re-establishment of diversity, and, in many cases, the percentage of efficacy is greater than $90 \%$ [100]. FMT is considered as the "ultimate probiotics" because it directly changes the intestinal microbial composition of the host, thus restoring eubiosis and intestinal homeostasis. FMT donor screening is a key factor in the safety of the procedure in order to prevent iatrogenic infectious diseases that are potentially transmittable to the recipient [101] In fact, the international consensus on stool banking for FMT has recently established that donor stool must be tested for protozoa and helminths, including B. hominis, D. fragilis, G. duodenalis, Cryptosporidium spp., Isospora, and Microsporidia [102]. In addition, the donor must be negative in blood nematodes testing (i.e., S. stercoralis) [102], and particular attention is necessary for the parasitological screening of donors when recipients are children [103]. Remarkably, the fecal material (i.e., emulsion) can be stored frozen in a stool bank for use when needed [103]. Indeed, FMT requires a combination of expertise and appropriate methods to identify the best donors, including advanced clinical parasitology. 


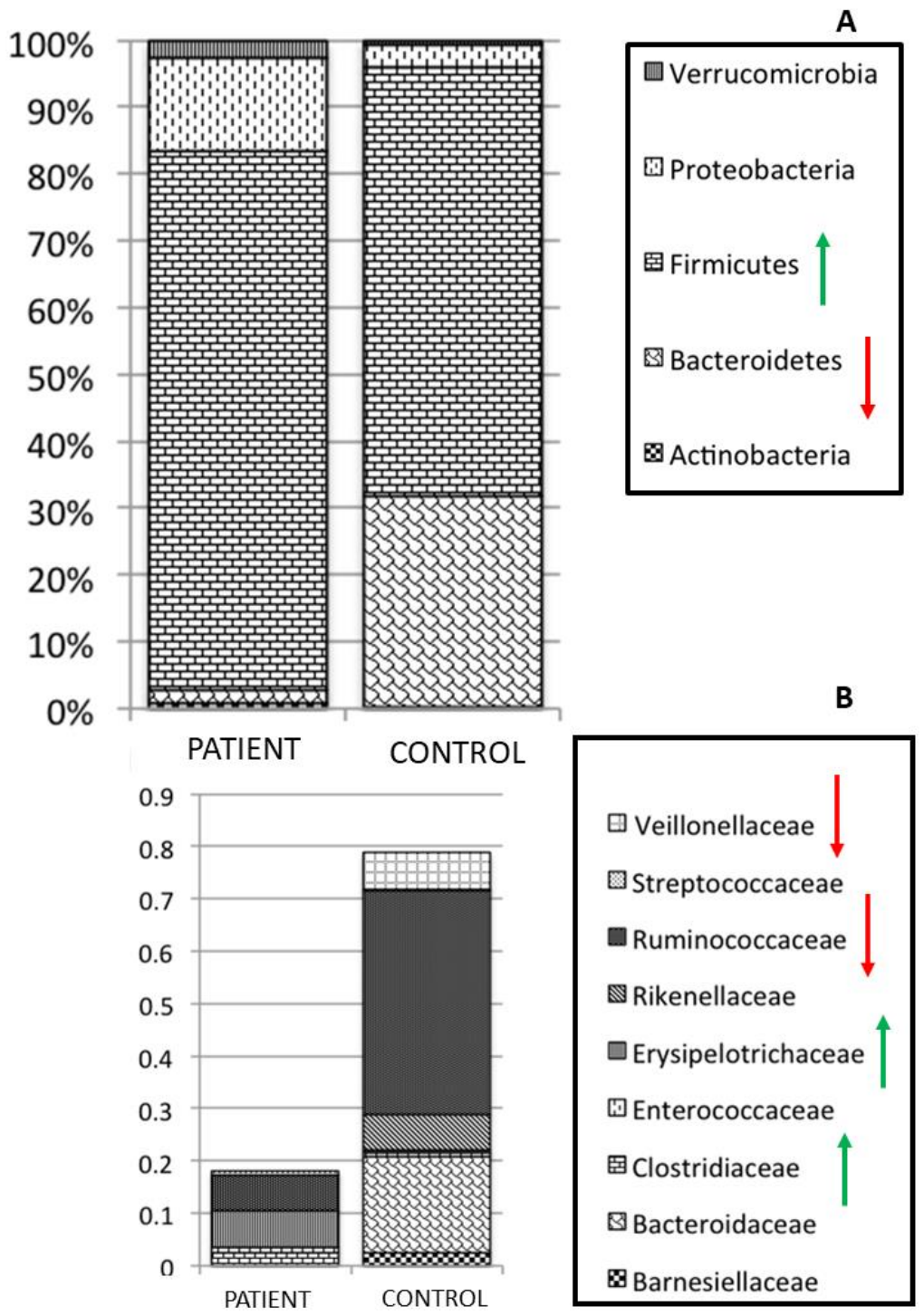

Figure 4. Faecal microbiota map of a patient affected by a Clostridium difficile infection. Panel (A,B) describe global distribution of the microbiota map at Phylum and Family taxonomic levels. Red and green arrows refer to the respective decrease and increase in microbial signatures associated with the disease-driven profile.

\section{Materials and Methods}

Regarding the literature review, this section of the paper was conducted to analyze the role of microorganisms (e.g., bacteria, viruses, fungi, worms, and protozoa) on the microbial communities of the gastrointestinal tract both under conditions of eubiosis and dysbiosis. The research was conducted on PubMed, using the following terms: "virus" "fungi", "worms", "protozoa", "microbiota" or "microbiome", "dysbiosis" or "eubiosis". Principal articles providing sufficient information about the relationship between the gut microbiota, NGS, clinical parasitology, and FMT were considered. The inclusion criteria for the study were as follows: (1) observational prospective and retrospective studies, casecontrol studies, cohort studies, or systemic review; (2) studies investigating gut microbiota profiles and parasites infection; (3) studies written in English. All the studies that did not fall in the stated criteria were excluded from the reviewing process. Regarding gut microbiota map generations, $16 \mathrm{~S}$ targeted metagenomics maps were reported for singlecase microbiota profiling under clinical microbiomics settings and in standardized and strict quality procedures. According to OPBG diagnostic procedures, three fecal samples 
for each subject were collected, processed to optimize microbial DNA extraction, amplified to generate $16 \mathrm{~S}$ rRNA libraries, pooled, quantified, and sequenced [104] by a MiSeq DX platform, in accordance with the manufacturer (Illumina, CA, USA). In addition to the wet part of the map generation pipeline, the dry bioinformatics module was assessed by an automated process designed by OPBG-GenomeUP in accordance with the OPBG patent. (Patent IT: PCT40659, EU: PCT/IT2017/000119, Metagenomic Method for in vitro diagnosis of intestinal disbiosis). Regarding shotgun procedures, before DNA extraction, differential sample homogenization (Precellys 24 original tissue homogenizer, (Bertin Instruments, Montigny-le-Bretonneux, France) was performed to optimize parasite and bacteria DNA extraction. Hence, AllPrep Power DNA/RNA Kit was exploited to provide shotgun DNA library templates (bacteriome, parasitome). Library preparation was set up by using Illumina ${ }^{\circledR}$ DNA Prep, (M) Tagmentation (96 Samples), IDT ${ }^{\circledR}$ for Illumina ${ }^{\circledR}$ DNA UD Indexes Set A, NextSeq 550 High Output Kit v2.5 (300 Cycles) according to Illumina specific instructions. Sequencing was performed on the NextSeq550 platform, ensuring at least a sequencing depth of 50-100 M reads/sample. For the dry protocol, a preprocessing procedure was assured by the removal of the input sequences containing regions of low quality/complexity and readings of less than 50 nucleotides. Only reads passing QC filters were directed to the following steps, in which data were mapped against the human genome. In the third step, a comparison with reference databases was undertaken, and taxonomic annotation was provided by processing GenBank and RefSeq databases. Alignments were filtered based on identity percentage and query coverage. Reports were generated as CSV files, HTML interactive tables, and Krona graphs [105]. Taxonomic and functional annotation were processed by Python statistics modules.

\section{Conclusions}

Over the last two decades, helminths and protozoans, previously considered only as pathogens, have been being increasingly suggested as also commensal, protective, or even curative microorganisms. These findings essentially point out that most of these primarily considered "parasites" could have an evolutionary history, tipping the balance towards commensalism, where they have adapted to live off the host without causing any harm. However, it is important to keep in mind that for most of these data, there are other studies that have found opposing results. A likely explanation for these differences can be attributed to various parameters affecting the study design and protocols. The method of analysis, which includes the type of sample used for sequencing, the workflow standardization, and lab-to-lab or operator variability, can create important biases in the results. Moreover, the majority of the studies rely on fecal samples, which does not give enough information on the localization of the parasite within the GI tract. The characterization of the human gut parasitome is now urgent, but this still requires time and new tools. The "-omics" analyses, i.e., (meta)genomics, (meta)transcriptomics, (meta)proteomics, (meta)metabolomics), represent a robust tool for such types of studies [106]. In this context, the application of "big data" methodologies to GM may boost this intervention. The introduction of sequencing technologies has revolutionized the field, enabling investigators to characterize microbial communities. By utilizing larger datasets, researchers are able to design large-scale studies to ask (and answer) complex questions. Metadata associated with samples are becoming an increasingly large contributor to microbiome big data and the challenges associated with streamlining data analysis. The successful application of big microbiome dataset analysis has already provided relevant insights for other areas of research, such as epidemiology, agriculture, and healthcare. Since gut microbiota composition differs widely according to host genetics, diet, lifestyle, geographical location, and disease burden, the application of big data methodologies to gut microbiota and parasitome profiling could be of utmost importance in developing a wide understanding of various infectious diseases. The reach of a new type of clinical parasitology, encountering the approaches and needs of the clinical microbiomics [107], may contribute to the new data-driven era in 
medicine, establishing new connections with other big data and genome-wide association links, opening the way to a novel holobiont perspective in infectious diseases.

Author Contributions: Conceptualization, S.P., L.P.; resources, L.P.; data curation, A.R., F.D.C., S.G., S.P., M.V.R.; writing-original draft preparation, S.P., M.V.R. and L.P.; writing-review and editing, S.P., M.V.R., F.D.C. and L.P. All authors have read and agreed to the published version of the manuscript.

Funding: Italian Ministry of Health: Ricerca Corrente 2020 and 2021, assigned to L.P.

Data Availability Statement: Not applicable.

Acknowledgments: We wish to thank all the staff of the Microbiomics and Human Microbiome Units.

Conflicts of Interest: The authors declare no conflict of interest.

\section{References}

1. Bäckhed, F.; Ley, R.E.; Sonnenburg, J.L.; Peterson, D.A.; Gordon, J.I. Host-Bacterial Mutualism in the Human Intestine. Science 2005, 307, 1915-1920. [CrossRef]

2. Eckburg, P.B.; Bik, E.M.; Bernstein, C.N.; Purdom, E.; Dethlefsen, L.; Sargent, M.; Gill, S.R.; Nelson, K.E.; Relman, D.A. Diversity of the Human Intestinal Microbial Flora. Science 2005, 308, 1635-1638. [CrossRef]

3. Qin, J.; Li, R.; Raes, J.; Arumugam, M.; Burgdorf, K.S.; Manichanh, C.; Nielsen, T.; Pons, N.; Levenez, F.; Yamada, T.; et al. A Human Gut Microbial Gene Catalogue Established by Metagenomic Sequencing. Nature 2010, 464, 59-65. [CrossRef]

4. Bancroft, A.J.; Hayes, K.S.; Grencis, R.K. Life on the Edge: The Balance between Macrofauna, Microflora and Host Immunity. Trends Parasitol. 2012, 28, 93-98. [CrossRef] [PubMed]

5. Mazmanian, S.K.; Liu, C.H.; Tzianabos, A.O.; Kasper, D.L. An Immunomodulatory Molecule of Symbiotic Bacteria Directs Maturation of the Host Immune System. Cell 2005, 122, 107-118. [CrossRef]

6. Becattini, S.; Taur, Y.; Pamer, E.G. Antibiotic-Induced Changes in the Intestinal Microbiota and Disease. Trends Mol. Med. 2016, 22, 458-478. [CrossRef] [PubMed]

7. Becattini, S.; Littmann, E.R.; Carter, R.A.; Kim, S.G.; Morjaria, S.M.; Ling, L.; Gyaltshen, Y.; Fontana, E.; Taur, Y.; Leiner, I.M.; et al. Commensal Microbes Provide First Line Defense against Listeria Monocytogenes Infection. J. Exp. Med. 2017, 214, 1973-1989. [CrossRef]

8. Sekirov, I.; Tam, N.M.; Jogova, M.; Robertson, M.L.; Li, Y.; Lupp, C.; Finlay, B.B. Antibiotic-Induced Perturbations of the Intestinal Microbiota Alter Host Susceptibility to Enteric Infection. Infect. Immun. 2008, 76, 4726-4736. [CrossRef] [PubMed]

9. Abt, M.C.; Osborne, L.C.; Monticelli, L.A.; Doering, T.A.; Alenghat, T.; Sonnenberg, G.F.; Paley, M.A.; Antenus, M.; Williams, K.L.; Erikson, J.; et al. Commensal Bacteria Calibrate the Activation Threshold of Innate Antiviral Immunity. Immunity 2012, 37, 158-170. [CrossRef] [PubMed]

10. Molloy, M.J.; Bouladoux, N.; Belkaid, Y. Intestinal Microbiota: Shaping Local and Systemic Immune Responses. Semin. Immunol. 2012, 24, 58-66. [CrossRef] [PubMed]

11. Alexander, K.L.; Targan, S.R.; Elson, C.O. Microbiota Activation and Regulation of Innate and Adaptive Immunity. Immunol. Rev. 2014, 260, 206-220. [CrossRef] [PubMed]

12. Zhang, Y.-J.; Li, S.; Gan, R.-Y.; Zhou, T.; Xu, D.-P.; Li, H.-B. Impacts of Gut Bacteria on Human Health and Diseases. Int. J. Mol. Sci. 2015, 16, 7493-7519. [CrossRef]

13. Putignani, L.; Del Chierico, F.; Vernocchi, P.; Cicala, M.; Cucchiara, S.; Dallapiccola, B. Dysbiotrack Study Group Gut Microbiota Dysbiosis as Risk and Premorbid Factors of IBD and IBS Along the Childhood-Adulthood Transition. Inflamm. Bowel Dis. 2016, 22, 487-504. [CrossRef]

14. Mariat, D.; Firmesse, O.; Levenez, F.; Guimarăes, V.; Sokol, H.; Doré, J.; Corthier, G.; Furet, J.-P. The Firmicutes/Bacteroidetes Ratio of the Human Microbiota Changes with Age. BMC Microbiol. 2009, 9, 123. [CrossRef]

15. Putignani, L.; Del Chierico, F.; Petrucca, A.; Vernocchi, P.; Dallapiccola, B. The Human Gut Microbiota: A Dynamic Interplay with the Host from Birth to Senescence Settled during Childhood. Pediatr. Res. 2014, 76, 2-10. [CrossRef]

16. Del Chierico, F.; Vernocchi, P.; Bonizzi, L.; Carsetti, R.; Castellazzi, A.M.; Dallapiccola, B.; de Vos, W.; Guerzoni, M.E.; Manco, M.; Marseglia, G.L.; et al. Early-Life Gut Microbiota under Physiological and Pathological Conditions: The Central Role of Combined Meta-Omics-Based Approaches. J. Proteom. 2012, 75, 4580-4587. [CrossRef]

17. Rawls, J.F.; Mahowald, M.A.; Ley, R.E.; Gordon, J.I. Reciprocal Gut Microbiota Transplants from Zebrafish and Mice to Germ-Free Recipients Reveal Host Habitat Selection. Cell 2006, 127, 423-433. [CrossRef] [PubMed]

18. Putignani, L.; Dallapiccola, B. Foodomics as Part of the Host-Microbiota-Exposome Interplay. J. Proteom. 2016, 147, 3-20. [CrossRef] [PubMed]

19. Lynch, S.V.; Pedersen, O. The Human Intestinal Microbiome in Health and Disease. N. Engl. J. Med. 2016, 375, 2369-2379. [CrossRef]

20. Bobardt, S.D.; Dillman, A.R.; Nair, M.G. The Two Faces of Nematode Infection: Virulence and Immunomodulatory Molecules From Nematode Parasites of Mammals, Insects and Plants. Front. Microbiol. 2020, 11, 577846. [CrossRef] 
21. Kaiko, G.E.; Horvat, J.C.; Beagley, K.W.; Hansbro, P.M. Immunological Decision-Making: How Does the Immune System Decide to Mount a Helper T-Cell Response? Immunology 2008, 123, 326-338. [CrossRef] [PubMed]

22. Nicholson, J.K.; Holmes, E.; Lindon, J.C.; Wilson, I.D. The Challenges of Modeling Mammalian Biocomplexity. Nat. Biotechnol. 2004, 22, 1268-1274. [CrossRef]

23. Manichanh, C.; Rigottier-Gois, L.; Bonnaud, E.; Gloux, K.; Pelletier, E.; Frangeul, L.; Nalin, R.; Jarrin, C.; Chardon, P.; Marteau, P.; et al. Reduced Diversity of Faecal Microbiota in Crohn's Disease Revealed by a Metagenomic Approach. Gut 2006, 55, $205-211$. [CrossRef] [PubMed]

24. Darfeuille-Michaud, A.; Boudeau, J.; Bulois, P.; Neut, C.; Glasser, A.-L.; Barnich, N.; Bringer, M.-A.; Swidsinski, A.; Beaugerie, L.; Colombel, J.-F. High Prevalence of Adherent-Invasive Escherichia Coli Associated with Ileal Mucosa in Crohn's Disease. Gastroenterology 2004, 127, 412-421. [CrossRef] [PubMed]

25. Swidsinski, A.; Ladhoff, A.; Pernthaler, A.; Swidsinski, S.; Loening-Baucke, V.; Ortner, M.; Weber, J.; Hoffmann, U.; Schreiber, S.; Dietel, M.; et al. Mucosal Flora in Inflammatory Bowel Disease. Gastroenterology 2002, 122, 44-54. [CrossRef]

26. Parfrey, L.W.; Walters, W.A.; Knight, R. Microbial Eukaryotes in the Human Microbiome: Ecology, Evolution, and Future Directions. Front. Microbiol. 2011, 2, 153. [CrossRef]

27. Human Microbiome Project Consortium. Structure, Function and Diversity of the Healthy Human Microbiome. Nature 2012, 486, 207-214. [CrossRef] [PubMed]

28. Hewitson, J.P.; Maizels, R.M. Vaccination against Helminth Parasite Infections. Expert Rev. Vaccines 2014, 13, 473-487. [CrossRef] [PubMed]

29. Cacciò, S.M.; Putignani, L. Epidemiology of Human Cryptosporidiosis. Cryptosporidium Parasite Dis. 2014, 43-79. [CrossRef]

30. Norman, J.M.; Handley, S.A.; Virgin, H.W. Kingdom-Agnostic Metagenomics and the Importance of Complete Characterization of Enteric Microbial Communities. Gastroenterology 2014, 146, 1459-1469. [CrossRef] [PubMed]

31. Nyholm, L.; Koziol, A.; Marcos, S.; Botnen, A.B.; Aizpurua, O.; Gopalakrishnan, S.; Limborg, M.T.; Gilbert, M.T.P.; Alberdi, A. Holo-Omics: Integrated Host-Microbiota Multi-Omics for Basic and Applied Biological Research. iScience 2020, $23,101414$. [CrossRef]

32. Putignani, L.; Gasbarrini, A.; Dallapiccola, B. Potential of Multiomics Technology in Precision Medicine. Curr. Opin. Gastroenterol. 2019, 35, 491-498. [CrossRef] [PubMed]

33. Matijašić, M.; Meštrović, T.; Paljetak, H.Č.; Perić, M.; Barešić, A.; Verbanac, D. Gut Microbiota beyond Bacteria-Mycobiome, Virome, Archaeome, and Eukaryotic Parasites in IBD. Int. J. Mol. Sci. 2020, 21, 2668. [CrossRef]

34. Zuo, T.; Wong, S.H.; Lam, K.; Lui, R.; Cheung, K.; Tang, W.; Ching, J.Y.L.; Chan, P.K.S.; Chan, M.C.W.; Wu, J.C.Y.; et al Bacteriophage Transfer during Faecal Microbiota Transplantation in Clostridium Difficile Infection Is Associated with Treatment Outcome. Gut 2018, 67, 634-643. [CrossRef]

35. Dalmasso, M.; Hill, C.; Ross, R.P. Exploiting Gut Bacteriophages for Human Health. Trends Microbiol. 2014, 22, 399-405. [CrossRef]

36. Jonas, O.; Seifman, R. Do We Need a Global Virome Project? Lancet Glob. Health 2019, 7, e1314-e1316. [CrossRef]

37. Minot, S.; Bryson, A.; Chehoud, C.; Wu, G.D.; Lewis, J.D.; Bushman, F.D. Rapid Evolution of the Human Gut Virome. Proc. Natl. Acad. Sci. USA 2013, 110, 12450-12455. [CrossRef]

38. Townsend, E.M.; Kelly, L.; Muscatt, G.; Box, J.D.; Hargraves, N.; Lilley, D.; Jameson, E. The Human Gut Phageome: Origins and Roles in the Human Gut Microbiome. Front. Cell. Infect. Microbiol. 2021, 11, 643214. [CrossRef] [PubMed]

39. Mirzaei, M.K.; Maurice, C.F. Ménage à Trois in the Human Gut: Interactions between Host, Bacteria and Phages. Nat. Rev. Microbiol. 2017, 15, 397-408. [CrossRef]

40. Huffnagle, G.B.; Noverr, M.C. The Emerging World of the Fungal Microbiome. Trends Microbiol. 2013, 21, 334-341. [CrossRef]

41. David, L.A.; Maurice, C.F.; Carmody, R.N.; Gootenberg, D.B.; Button, J.E.; Wolfe, B.E.; Ling, A.V.; Devlin, A.S.; Varma, Y.; Fischbach, M.A.; et al. Diet Rapidly and Reproducibly Alters the Human Gut Microbiome. Nature 2014, 505, 559-563. [CrossRef]

42. Hoffmann, C.; Dollive, S.; Grunberg, S.; Chen, J.; Li, H.; Wu, G.D.; Lewis, J.D.; Bushman, F.D. Archaea and Fungi of the Human Gut Microbiome: Correlations with Diet and Bacterial Residents. PLoS ONE 2013, 8, e66019. [CrossRef]

43. Beheshti-Maal, A.; Shahrokh, S.; Ansari, S.; Mirsamadi, E.S.; Yadegar, A.; Mirjalali, H.; Zali, M.R. Gut Mycobiome: The Probable Determinative Role of Fungi in IBD Patients. Mycoses 2021, 64, 468-476. [CrossRef]

44. Ianiro, G.; Iorio, A.; Porcari, S.; Masucci, L.; Perno, C.F.; Gasbarrini, A.; Putignani, L.; Cam-marota, G. How the Gut Parasitome Affects Human Health.

45. Prommi, A.; Prombutara, P.; Watthanakulpanich, D.; Adisakwattana, P.; Kusolsuk, T.; Yoonuan, T.; Poodeepiyasawat, A.; Homsuwan, N.; Prummongkol, S.; Tanita, M.; et al. Intestinal Parasites in Rural Communities in Nan Province, Thailand: Changes in Bacterial Gut Microbiota Associated with Minute Intestinal Fluke Infection. Parasitology 2020, 147, 972-984. [CrossRef]

46. Farthing, M.J. Giardiasis. Gastroenterol. Clin. N. Am. 1996, 25, 493-515. [CrossRef]

47. Cryptosporidium-ScienceDirect. Available online: https://www.sciencedirect.com/science/article/pii/B97801281873190008 0X?via\%3Dihub (accessed on 21 September 2021).

48. Putignani, L.; Menichella, D. Global Distribution, Public Health and Clinical Impact of the Protozoan Pathogen Cryptosporidium. Interdiscip. Perspect. Infect. Dis. 2010, 2010, 753512. [CrossRef] [PubMed]

49. Caradonna, T.; Marangi, M.; Del Chierico, F.; Ferrari, N.; Reddel, S.; Bracaglia, G.; Normanno, G.; Putignani, L.; Giangaspero, A. Detection and Prevalence of Protozoan Parasites in Ready-to-Eat Packaged Salads on Sale in Italy. Food Microbiol. 2017, 67, 67-75. [CrossRef] [PubMed] 
50. Formenti, F.; Cortés, A.; Brindley, P.J.; Cantacessi, C.; Rinaldi, G. A Bug's Life: Delving into the Challenges of Helminth Microbiome Studies. PLoS Negl. Trop. Dis. 2020, 14, e0008446. [CrossRef]

51. White, E.C.; Houlden, A.; Bancroft, A.J.; Hayes, K.S.; Goldrick, M.; Grencis, R.K.; Roberts, I.S. Manipulation of Host and Parasite Microbiotas: Survival Strategies during Chronic Nematode Infection. Sci. Adv. 2018, 4, eaap7399. [CrossRef] [PubMed]

52. Holzscheiter, M.; Layland, L.E.; Loffredo-Verde, E.; Mair, K.; Vogelmann, R.; Langer, R.; Wagner, H.; Prazeres da Costa, C. Lack of Host Gut Microbiota Alters Immune Responses and Intestinal Granuloma Formation during Schistosomiasis. Clin. Exp. Immunol. 2014, 175, 246-257. [CrossRef] [PubMed]

53. Yason, J.A.; Liang, Y.R.; Png, C.W.; Zhang, Y.; Tan, K.S.W. Interactions between a Pathogenic Blastocystis Subtype and Gut Microbiota: In Vitro and in Vivo Studies. Microbiome 2019, 7, 30. [CrossRef] [PubMed]

54. Toro-Londono, M.A.; Bedoya-Urrego, K.; Garcia-Montoya, G.M.; Galvan-Diaz, A.L.; Alzate, J.F. Intestinal Parasitic Infection Alters Bacterial Gut Microbiota in Children. PeerJ 2019, 7, e6200. [CrossRef]

55. Alzate, J.F.; Toro-Londoño, M.; Cabarcas, F.; Garcia-Montoya, G.; Galvan-Diaz, A. Contrasting Microbiota Profiles Observed in Children Carrying Either Blastocystis Spp. or the Commensal Amoebas Entamoeba Coli or Endolimax Nana. Sci. Rep. 2020, 10, 15354. [CrossRef] [PubMed]

56. Rosa, B.A.; Supali, T.; Gankpala, L.; Djuardi, Y.; Sartono, E.; Zhou, Y.; Fischer, K.; Martin, J.; Tyagi, R.; Bolay, F.K.; et al. Differential Human Gut Microbiome Assemblages during Soil-Transmitted Helminth Infections in Indonesia and Liberia. Microbiome 2018, 6, 33. [CrossRef]

57. Giacomin, P.; Zakrzewski, M.; Jenkins, T.P.; Su, X.; Al-Hallaf, R.; Croese, J.; de Vries, S.; Grant, A.; Mitreva, M.; Loukas, A.; et al. Changes in Duodenal Tissue-Associated Microbiota Following Hookworm Infection and Consecutive Gluten Challenges in Humans with Coeliac Disease. Sci. Rep. 2016, 6, 36797. [CrossRef]

58. Cortés, A.; Clare, S.; Costain, A.; Almeida, A.; McCarthy, C.; Harcourt, K.; Brandt, C.; Tolley, C.; Rooney, J.; Berriman, M.; et al. Baseline Gut Microbiota Composition Is Associated With Schistosoma Mansoni Infection Burden in Rodent Models. Front. Immunol. 2020, 11, 593838. [CrossRef]

59. Jenkins, T.P.; Pritchard, D.I.; Tanasescu, R.; Telford, G.; Papaiakovou, M.; Scotti, R.; Cortés, A.; Constantinescu, C.S.; Cantacessi, C. Experimental Infection with the Hookworm, Necator Americanus, Is Associated with Stable Gut Microbial Diversity in Human Volunteers with Relapsing Multiple Sclerosis. BMC Biol. 2021, 19, 74. [CrossRef]

60. Pane, S.; Sacco, A.; Iorio, A.; Romani, L.; Putignani, L. Strongyloides Stercoralis Infestation in a Child: How a Nematode Can Affect Gut Microbiota. Int. J. Mol. Sci. 2021, 22, 2131. [CrossRef]

61. Morton, E.R.; Lynch, J.; Froment, A.; Lafosse, S.; Heyer, E.; Przeworski, M.; Blekhman, R.; Ségurel, L. Variation in Rural African Gut Microbiota Is Strongly Correlated with Colonization by Entamoeba and Subsistence. PLoS Genet. 2015, 11, e1005658. [CrossRef]

62. Iebba, V.; Santangelo, F.; Totino, V.; Pantanella, F.; Monsia, A.; Di Cristanziano, V.; Di Cave, D.; Schippa, S.; Berrilli, F.; D’Alfonso, R. Gut Microbiota Related to Giardia Duodenalis, Entamoeba Spp. and Blastocystis Hominis Infections in Humans from Côte d'Ivoire. J. Infect. Dev. Ctries 2016, 10, 1035-1041. [CrossRef] [PubMed]

63. Iyer, L.R.; Verma, A.K.; Paul, J.; Bhattacharya, A. Phagocytosis of Gut Bacteria by Entamoeba Histolytica. Front. Cell. Infect. Microbiol. 2019, 9, 34. [CrossRef]

64. Midha, A.; Schlosser, J.; Hartmann, S. Reciprocal Interactions between Nematodes and Their Microbial Environments. Front. Cell. Infect. Microbiol. 2017, 7, 144. [CrossRef] [PubMed]

65. Beghini, F.; Pasolli, E.; Truong, T.D.; Putignani, L.; Cacciò, S.M.; Segata, N. Large-Scale Comparative Metagenomics of Blastocystis, a Common Member of the Human Gut Microbiome. ISME J. 2017, 11, 2848-2863. [CrossRef]

66. Andersen, L.O.; Stensvold, C.R. Blastocystis in Health and Disease: Are We Moving from a Clinical to a Public Health Perspective? J. Clin. Microbiol. 2016, 54, 524-528. [CrossRef] [PubMed]

67. Audebert, C.; Even, G.; Cian, A.; Blastocystis Investigation Group; Loywick, A.; Merlin, S.; Viscogliosi, E.; Chabé, M. Colonization with the Enteric Protozoa Blastocystis Is Associated with Increased Diversity of Human Gut Bacterial Microbiota. Sci. Rep. 2016, 6, 25255. [CrossRef]

68. Nagel, R.; Traub, R.J.; Allcock, R.J.N.; Kwan, M.M.S.; Bielefeldt-Ohmann, H. Comparison of Faecal Microbiota in BlastocystisPositive and Blastocystis-Negative Irritable Bowel Syndrome Patients. Microbiome 2016, 4, 47. [CrossRef] [PubMed]

69. Billy, V.; Lhotská, Z.; Jirků, M.; Kadlecová, O.; Frgelecová, L.; Parfrey, L.W.; Pomajbíková, K.J. Blastocystis Colonization Alters the Gut Microbiome and, in Some Cases, Promotes Faster Recovery From Induced Colitis. Front. Microbiol. 2021, $12,641483$. [CrossRef]

70. Stensvold, C.R.; van der Giezen, M. Associations between Gut Microbiota and Common Luminal Intestinal Parasites. Trends Parasitol. 2018, 34, 369-377. [CrossRef]

71. Scanlan, P.D.; Stensvold, C.R.; Rajilić-Stojanović, M.; Heilig, H.G.H.J.; De Vos, W.M.; O’Toole, P.W.; Cotter, P.D. The Microbial Eukaryote Blastocystis Is a Prevalent and Diverse Member of the Healthy Human Gut Microbiota. FEMS Microbiol. Ecol. 2014, 90, 326-330. [CrossRef] [PubMed]

72. Scanlan, P.D.; Stensvold, C.R.; Cotter, P.D. Development and Application of a Blastocystis Subtype-Specific PCR Assay Reveals That Mixed-Subtype Infections Are Common in a Healthy Human Population. Appl. Environ. Microbiol. 2015, 81, 4071-4076. [CrossRef] 
73. Holtman, G.A.; Kranenberg, J.J.; Blanker, M.H.; Ott, A.; Lisman-van Leeuwen, Y.; Berger, M.Y. Dientamoeba Fragilis Colonization Is Not Associated with Gastrointestinal Symptoms in Children at Primary Care Level. Fam. Pract. 2017, 34, 25-29. [CrossRef] [PubMed]

74. Petersen, A.M.; Stensvold, C.R.; Mirsepasi, H.; Engberg, J.; Friis-Møller, A.; Porsbo, L.J.; Hammerum, A.M.; Nordgaard-Lassen, I.; Nielsen, H.V.; Krogfelt, K.A. Active Ulcerative Colitis Associated with Low Prevalence of Blastocystis and Dientamoeba Fragilis Infection. Scand. J. Gastroenterol. 2013, 48, 638-639. [CrossRef]

75. Coskun, A.; Malatyali, E.; Ertabaklar, H.; Yasar, M.B.; Karaoglu, A.O.; Ertug, S. Blastocystis in Ulcerative Colitis Patients: Genetic Diversity and Analysis of Laboratory Findings. Asian Pac. J. Trop. Med. 2016, 9, 916-919. [CrossRef] [PubMed]

76. Krogsgaard, L.R.; Lee, O.; Johannesen, T.B.; Engsbro, A.L.; Stensvold, C.R.; Nielsen, H.V.; Bytzer, P. Characteristics of the Bacterial Microbiome in Association with Common Intestinal Parasites in Irritable Bowel Syndrome. Clin. Transl. Gastroenterol. $2018,9,161$. [CrossRef]

77. Berrilli, F.; Di Cave, D.; Cavallero, S.; D'Amelio, S. Interactions between Parasites and Microbial Communities in the Human Gut. Front. Cell. Infect. Microbiol. 2012, 2, 141. [CrossRef]

78. Dheilly, N.M.; Martínez Martínez, J.; Rosario, K.; Brindley, P.J.; Fichorova, R.N.; Kaye, J.Z.; Kohl, K.D.; Knoll, L.J.; Lukeš, J.; Perkins, S.L.; et al. Parasite Microbiome Project: Grand Challenges. PLoS Pathog. 2019, 15, e1008028. [CrossRef]

79. Chiu, C.Y.; Miller, S.A. Clinical Metagenomics. Nat. Rev. Genet. 2019, 20, 341-355. [CrossRef] [PubMed]

80. Hugenholtz, P.; Chuvochina, M.; Oren, A.; Parks, D.H.; Soo, R.M. Prokaryotic Taxonomy and Nomenclature in the Age of Big Sequence Data. ISME J. 2021, 15, 1879-1892. [CrossRef]

81. Marchesi, J.R.; Ravel, J. The Vocabulary of Microbiome Research: A Proposal. Microbiome 2015, 3, 31. [CrossRef]

82. Chistoserdovai, L. Functional Metagenomics: Recent Advances and Future Challenges. Biotechnol. Genet. Eng. Rev. 2010, 26, 335-352. [CrossRef]

83. Choi, K.Y.; Lee, T.K.; Sul, W.J. Metagenomic Analysis of Chicken Gut Microbiota for Improving Metabolism and Health of Chickens-A Review. Asian-Australas J. Anim. Sci. 2015, 28, 1217-1225. [CrossRef]

84. Breitwieser, F.P.; Lu, J.; Salzberg, S.L. A Review of Methods and Databases for Metagenomic Classification and Assembly. Brief. Bioinform. 2019, 20, 1125-1136. [CrossRef]

85. Campanaro, S.; Treu, L.; Kougias, P.G.; Zhu, X.; Angelidaki, I. Taxonomy of Anaerobic Digestion Microbiome Reveals Biases Associated with the Applied High Throughput Sequencing Strategies. Sci. Rep. 2018, 8, 1926. [CrossRef]

86. Fouhy, F.; Clooney, A.G.; Stanton, C.; Claesson, M.J.; Cotter, P.D. 16S RRNA Gene Sequencing of Mock Microbial PopulationsImpact of DNA Extraction Method, Primer Choice and Sequencing Platform. BMC Microbiol. 2016, 16, 123. [CrossRef] [PubMed]

87. Cole, J.R.; Wang, Q.; Fish, J.A.; Chai, B.; McGarrell, D.M.; Sun, Y.; Brown, C.T.; Porras-Alfaro, A.; Kuske, C.R.; Tiedje, J.M. Ribosomal Database Project: Data and Tools for High Throughput RRNA Analysis. Nucleic Acids Res. 2014, 42, D633-D642. [CrossRef]

88. Colwell, R.K. III.1 Biodiversity: Concepts, Patterns, and Measurement; Princeton University Press: Princeton, NJ, USA, 2009; pp. 257-263. ISBN 978-1-4008-3302-3.

89. Sala, C.; Vitali, S.; Giampieri, E.; do Valle, İ.F.; Remondini, D.; Garagnani, P.; Bersanelli, M.; Mosca, E.; Milanesi, L.; Castellani, G. Stochastic Neutral Modelling of the Gut Microbiota's Relative Species Abundance from next Generation Sequencing Data. BMC Bioinform. 2016, 17, 16. [CrossRef] [PubMed]

90. Weinstock, G.M. Genomic Approaches to Studying the Human Microbiota. Nature 2012, 489, 250-256. [CrossRef] [PubMed]

91. Durazzi, F.; Sala, C.; Castellani, G.; Manfreda, G.; Remondini, D.; De Cesare, A. Comparison between 16S RRNA and Shotgun Sequencing Data for the Taxonomic Characterization of the Gut Microbiota. Sci. Rep. 2021, 11, 3030. [CrossRef]

92. Del Chierico, F.; Abbatini, F.; Russo, A.; Quagliariello, A.; Reddel, S.; Capoccia, D.; Caccamo, R.; Ginanni Corradini, S.; Nobili, V.; De Peppo, F.; et al. Gut Microbiota Markers in Obese Adolescent and Adult Patients: Age-Dependent Differential Patterns. Front. Microbiol. 2018, 9, 1210. [CrossRef]

93. Del Chierico, F.; Nobili, V.; Vernocchi, P.; Russo, A.; De Stefanis, C.; Gnani, D.; Furlanello, C.; Zandonà, A.; Paci, P.; Capuani, G.; et al. Gut Microbiota Profiling of Pediatric Nonalcoholic Fatty Liver Disease and Obese Patients Unveiled by an Integrated Meta-Omics-Based Approach. Hepatology 2017, 65, 451-464. [CrossRef]

94. Mortera, S.L.; Vernocchi, P.; Basadonne, I.; Zandonà, A.; Chierici, M.; Durighello, M.; Marzano, V.; Gardini, S.; Gasbarrini, A.; Urbani, A.; et al. A Metaproteomic-Based Gut Microbiota Profiling in Children Affected by Autism Spectrum Disorders. J. Proteom. 2021, 251, 104407. [CrossRef] [PubMed]

95. Quagliariello, A.; Del Chierico, F.; Russo, A.; Reddel, S.; Conte, G.; Lopetuso, L.R.; Ianiro, G.; Dallapiccola, B.; Cardona, F.; Gasbarrini, A.; et al. Gut Microbiota Profiling and Gut-Brain Crosstalk in Children Affected by Pediatric Acute-Onset Neuropsychiatric Syndrome and Pediatric Autoimmune Neuropsychiatric Disorders Associated With Streptococcal Infections. Front. Microbiol. 2018, 9, 675. [CrossRef] [PubMed]

96. Dobson, G.; Hickey, C.; Trinder, J. Clostridium Difficile Colitis Causing Toxic Megacolon, Severe Sepsis and Multiple Organ Dysfunction Syndrome. Intensive Care Med. 2003, 29, 1030. [CrossRef]

97. Mylonakis, E.; Ryan, E.T.; Calderwood, S.B. Clostridium Difficile-Associated Diarrhea: A Review. Arch. Intern. Med. 2001, 161, 525-533. [CrossRef] [PubMed]

98. Smits, W.K.; Lyras, D.; Lacy, D.B.; Wilcox, M.H.; Kuijper, E.J. Clostridium Difficile Infection. Nat. Rev. Dis. Primers 2016, 2, 16020. [CrossRef] 
99. Chang, J.Y.; Antonopoulos, D.A.; Kalra, A.; Tonelli, A.; Khalife, W.T.; Schmidt, T.M.; Young, V.B. Decreased Diversity of the Fecal Microbiome in Recurrent Clostridium Difficile-Associated Diarrhea. J. Infect. Dis. 2008, 197, 435-438. [CrossRef]

100. Guo, B.; Harstall, C.; Louie, T.; Veldhuyzen van Zanten, S.; Dieleman, L.A. Systematic Review: Faecal Transplantation for the Treatment of Clostridium Difficile-Associated Disease. Aliment. Pharmacol. Ther. 2012, 35, 865-875. [CrossRef]

101. Cammarota, G.; Ianiro, G.; Tilg, H.; Rajilić-Stojanović, M.; Kump, P.; Satokari, R.; Sokol, H.; Arkkila, P.; Pintus, C.; Hart, A.; et al. European Consensus Conference on Faecal Microbiota Transplantation in Clinical Practice. Gut 2017, 66, 569-580. [CrossRef]

102. Cammarota, G.; Ianiro, G.; Kelly, C.R.; Mullish, B.H.; Allegretti, J.R.; Kassam, Z.; Putignani, L.; Fischer, M.; Keller, J.J.; Costello, S.P.; et al. International Consensus Conference on Stool Banking for Faecal Microbiota Transplantation in Clinical Practice. Gut 2019, 68, 2111-2121. [CrossRef]

103. Keller, J.J.; Ooijevaar, R.E.; Hvas, C.L.; Terveer, E.M.; Lieberknecht, S.C.; Högenauer, C.; Arkkila, P.; Sokol, H.; Gridnyev, O.; Mégraud, F.; et al. A Standardised Model for Stool Banking for Faecal Microbiota Transplantation: A Consensus Report from a Multidisciplinary UEG Working Group. United Eur. Gastroenterol. J. 2021, 9, 229-247. [CrossRef] [PubMed]

104. Klindworth, A.; Pruesse, E.; Schweer, T.; Peplies, J.; Quast, C.; Horn, M.; Glöckner, F.O. Evaluation of General 16S Ribosomal RNA Gene PCR Primers for Classical and Next-Generation Sequencing-Based Diversity Studies. Nucleic Acids Res. 2013, 41, e1. [CrossRef] [PubMed]

105. Ondov, B.D.; Bergman, N.H.; Phillippy, A.M. Interactive Metagenomic Visualization in a Web Browser. BMC Bioinform. 2011, 12, 385. [CrossRef]

106. Marzano, V.; Mancinelli, L.; Bracaglia, G.; Del Chierico, F.; Vernocchi, P.; Di Girolamo, F.; Garrone, S.; Tchidjou Kuekou, H.; D'Argenio, P.; Dallapiccola, B.; et al. "Omic" Investigations of Protozoa and Worms for a Deeper Understanding of the Human Gut "Parasitome". PLoS Negl. Trop. Dis. 2017, 11, e0005916. [CrossRef] [PubMed]

107. Scherz, V.; Greub, G.; Bertelli, C. Building up a Clinical Microbiota Profiling: A Quality Framework Proposal. Crit. Rev. Microbiol. 2021, 1-20. [CrossRef] 